systematic order, but you must gather them from various monographs, journals and proceedings, which are not easy to procure. This disheartens the young student. The same is to a great extent also true of butterflies, especially of Noctuidæ, and of other orders of insects, although the want is supplied in Lepidoptera more fully than in any other. But even this order, beyond the Diurnals, although hundreds of species are described, has not been brought together in systematic arrangement. The material is at hand, and nothing is wanting but a competent editor and an accommodating publisher to bring out a series of works which would contribute immeasurably to our progress.

My second suggestion is, that it would be interesting to know the extent, character and condition of the larger public and private collections in the country, with a mention of the varieties they contain. This might embrace two sections, those of our own species and those of foreign countries. A paper on this subject for next meeting would be an interesting contribution, and I hope some gentleman will furnish it; or let some member be appointed, so that there may be no conflict, and the whole field be open to him. No doubt the owners of private collections and the curators of public ones would cheerfully render him their counsel and aid.

And now, gentlemen, congratulating you upon our meeting again, let us proceed to our business and prosecute it with vigor, patience and order. JOHN G. MORRIS.

At the conclusion of the address a vote of thanks was tendered to the President, coupled with the request that the copy be sent to the Canadian EnTomologist for publication, which was kindly assented to.

(To be Continued.)

\title{
CARBOLIC ACID AS A PREVENTIVE OF INSECT RAVAGES.
}

(Read before the Sub-Section of Entomology of the A. A. A. S.)

BY A. J. COOK, LANSING, MICH.

One year ago I gave at the Boston meeting of the Association for the Advancement of Science the results of some experiments in the use of London purple to destroy the codling moth larva, and bisulphide of carbon in fighting the cabbage maggot and squash borer. These experi- 
ments have been repeated the present season, and with results no less favorable than those reported one year ago. I think it is an established fact that the methods recommended are valuable. They not only seem reliable, but they promise to be the cheapest and most desirable modes that can be made practicable on all occasions.

As stated last year, the bisulphide of carbon will also destroy the radish maggot (Anthomyia raphani), but owing to the great number of plants to be treated, the amount of the liquid necessary to do thorough work is large, and so the expense is perhaps too great to warrant its use in case of this insect. The present season I tried to see if we might not make the application in a few places about the bed, at some distance apart, and still effect our purpose to destroy the maggots. The result does not recommend this iiquid for the destruction of the radish Anthomyia with the same emphasis that we may safely give in advising its use for the cabbage Anthomyia and the squash Ægerian. This fact led me to cast about for some more desirable agent to be used against the radish fly, and it occurred to me that carbolic acid, which is not only very repellant to insects, but also quite as remarkable in retaining its obnoxious odor for a long time, might be made most serviceable in this warfare.

I prepared some of this material as follows: To two quarts of soft soap I added two gallons of water. This was then heated to a boiling temperature, when one pint of carbolic acid (in a crude state) was added. This mixture is then set away in a barrel or other vessel, and is ready for use as occasion may require. I mixed one part of this liquid to fifty parts of water, to be used on the radish plants. It was used by three parties in three places. Mr. Lee used it in the College garden, a student-Mr. E. Hale-used it on a bed specially prepared, and I used it in my own garden. Mr. Lee sprinkled it on the plants and poured it into a trench made close beside the row of plants. Mr. Hale and myself sprinkled it directly on the plants. Messrs. Lee and Hale made but one application and found that it kept the insects at bay for about two weeks. Even this proved of no little service. I made the application once every week, and the radishes were almost entirely free from the maggots. My bed was seventy or eighty rods from the other beds. But I caught the flies about my garden, and plants near by, not treated, were badly injured by the maggots. Two cautions should be urged; first, sprinkle the plants as soon as they are up, and thereafter every week or ten days; secondly, the mixture, if sprinkled directly upon the plants, must not be so concentrated 
as to injure the plants. My experiments this season make me feel certain that this will prove a valuable remedy, and if cheaper, it may even replace the explosive bisulphide of carbon in fighting the cabbage maggot and the squash Ægerian.

About my house at the Michigan Agricultural College I have planted a little apple orchard of eight trees. The trunks and larger branches of these trees have been thoroughly washed twice each spring, the last week of May and the last week of June, with soft soap. A neighbor but a stone's throw distant set out some fine primates about the same time that I set out my trees. He does not believe in the use of soft soap, practically at least, and his trees are sorely disfigured and greatly injured by the Saperda candida and the $S$. cretata, while my trees are smooth and admired by all. I have some pear trees in the same orchard which were not treated with the soap, one of which has been much injured by the borers.

This year I used the undiluted carbolic mixture instead of the soft soap. I fully believe this to be an improvement on the soap alone, as in some cases, if but one or even two applications of the soap are made, the effect is not so long continued as to entirely prevent the borers from egg laying. The carbolic acid will tend to extend the period so that I believe two applications will in every case repel the beetles.

"ON SOME NORTH AMERICAN TINEIDE, BY THOMAS, LORD WALSINGHAM, F. Z. S."

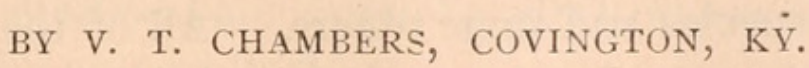

The above is the title of a paper received from the author, and published in the Proceedings of the Zoological Society of London (February I5th, I88I), in which his Lordship characterizes three new genera: Phryganeopsis-one species, P. brunnea; Aræolepia-one species, subfasiella; and Euceratia-two species, castella and securella. He also describes as new Calantica polita, Plutella interrupta, $P$. albidorsella and $P$. vanella; Cerostoma falciferella, C. cervella, C. sublulella, C. dentiferella, C. canariella and C. frustella; Depressaria sabulella, D. argillacea, $D$. arnicella, D. klamathiana, D. posticella, D. nubiferella, D. parilella 


\section{$2 \mathrm{BHL}$ Biodiversity Heritage Library}

Cook, Albert John. 1881. "Carbolic acid as a preventive of insect ravages." The Canadian entomologist 13, 189-191. https://doi.org/10.4039/Ent13189-9.

View This Item Online: https://www.biodiversitylibrary.org/item/22092

DOI: https://doi.org/10.4039/Ent13189-9

Permalink: https://www.biodiversitylibrary.org/partpdf/27059

\section{Holding Institution}

MBLWHOI Library

\section{Sponsored by}

MBLWHOI Library

\section{Copyright \& Reuse}

Copyright Status: NOT_IN_COPYRIGHT

This document was created from content at the Biodiversity Heritage Library, the world's largest open access digital library for biodiversity literature and archives. Visit BHL at https://www.biodiversitylibrary.org. 